\title{
Phytotoxicity of Aqueous Ozone on Five Container-grown Nursery Species
}

\author{
Thomas Graham¹, Ping Zhang, Youbin Zheng, and Michael A. Dixon \\ Department of Environmental Biology, University of Guelph, Ontario, \\ N1G 2W1, Canada
}

Additional index words. Salix integra, Weigela florida, Spiraea japonica, Hydrangea paniculata, Physocarpus opulifolius, foliar applied oxidant

Abstract. The phytotoxic threshold of five woody perennial nursery crops to applications of aqueous ozone was investigated to determine if aqueous ozone could be used for remediation of recycled nursery irrigation water and for pathogen control. The perennial nursery crops [Salix integra Thunb. 'Hakura Nishiki'; Weigela florida Thunb. 'Alexandra'; Spiraea japonica L.f. 'Goldmound'; Hydrangea paniculata Seib. 'Grandiflora'; Physocarpus opulifolius L. Maxim. 'Summer Wine'] were evaluated for aqueous ozone phytotoxicity after 6 weeks of overhead spray irrigation in which five aqueous ozone treatments $\left(0,10.4,31.2,62.5,125.0 \mu \mathrm{mol} \cdot \mathrm{L}^{-1}\right)$ were applied on a daily basis. The concentrations applied represent levels useful for irrigation system maintenance (pathogen and biofilm control) with the highest levels selected to clearly demonstrate phytotoxicity. Aqueous ozone solutions were prepared and injected in-line during irrigation for 7.5 min every day for 6 weeks, after which growth parameters (leaf area, shoot dry weight, root dry weight, height, flower number) were measured and leaf injury was evaluated. High residual aqueous ozone $\left(62.5 \mu \mathrm{mol} \cdot \mathrm{L}^{-1}\right.$ or greater at emitter discharge; $0.3 \mathrm{~m}$ from canopy) in the irrigation water was shown to negatively affect the growth parameters measured; however, low residual ozone concentrations $(31.2$ $\mu \mathrm{mol} \cdot \mathrm{L}^{-1}$ or less at emitter discharge; $0.3 \mathrm{~m}$ from canopy) did not present any measurable risk to plant growth. Furthermore, even at higher dose levels, leaves produced during the treatment period showed reduced damage levels. It is concluded that ozone residuals of $31.2 \mu \mathrm{mol} \cdot \mathrm{L}^{-1}$ (at emitter discharge) can remain in overhead irrigation water without negatively affecting the crop species examined under the application protocols used. At the ozone concentrations demonstrated to be tolerable by the crop species examined, it is reasonable to surmise that control of pathogens at all points within the irrigation system will be achievable using aqueous ozone as part of an irrigation management strategy. The use of aqueous ozone in this fashion could also aid in dramatically reducing chemical residuals on crops by reducing the input requirements of traditional chemical controls.

In many of the world's largest greenhouse and nursery production regions, irrigation water supply (quality and quantity) and

Received for publication 11 Feb. 2009. Accepted for publication 15 Mar. 2009

This project was made possible through the financial support of the Agriculture Adaptation Council via the Canada-Ontario Research and Development Program (CORD).

We thank Tom Intven at Canadale Nurseries Ltd. for the plant material and Purification Research Technologies Incorporated (PRTI) for the ozonation systems used in this study. We also thank Linping Wang for her assistance during the lengthy harvest process. We thank Jennifer Llewellyn for her networking and extension work on this project as well as her editorial suggestions during the preparation of this manuscript. We also thank Michael Stasiak for his thoughtful editorial comments.

Mention of a trademark, proprietary product, or vendor does not constitute a guarantee or warranty of the product by the authors or the University of Guelph and does not imply its approval to the exclusion of other products or vendors that also may be suitable.

The research presented is a component of the author's $\mathrm{PhD}$ thesis.

${ }^{1}$ To whom reprint requests should be addressed; e-mail tgraham@uoguelph.ca.
2005). Adaptation to emerging market, social, and environmental realities will rely on improvements in resource use efficiency, creation of value-added products, and empowerment of growers to rapidly respond to dynamic consumer preferences. Effective water and pest management strategies that can deliver substantial savings in an environmentally benign fashion are an important component of future greenhouse and nursery management strategies. Aqueous ozone $\left[\mathrm{O}_{3(\mathrm{aq})}\right]$ technology can eliminate pathogens and many chemical contaminants in a wide range of water and wastewater streams without leaving many of the harmful chemical residues associated with other treatment technologies (e.g., chlorination). These properties make the technology attractive to horticultural production; however, data are lacking on the phytotoxicity of aqueous ozone (Fujiwara and Fujii, 2002).

Ozone $\left(\mathrm{O}_{3}\right)$ is a triatomic allotrope of oxygen most commonly associated with interception of high-energy ultraviolet radiation in the Earth's stratosphere or as a component of photochemical smog, a significant tropospheric pollution issue. As a constituent of photochemical smog, a nearly ubiquitous pollution vector in major greenhouse and nursery crop production regions, ozone pollution as a plant stress is an ongoing concern. Ozone gas has known and wellcharacterized phytotoxic effects such as reduced photosynthetic capacity and foliar reddening and necrosis (Davison and Barnes, 1998; Fiscus et al., 2005; Fuhrer and Booker, 2003; Heath, 1996; Sandermann, 1996). There is, however, limited yet compelling evidence that the phytotoxic properties of ozone (gas) are altered when the ozone exposure is in an aqueous form (Fujiwara and Fujii, 2002; Sloan and Engelke, 2005), although the mechanisms of this reduced toxicity are a subject for further research and debate. There is additional evidence that low-level ozone (gas) exposure can stimulate oxidative stress adaptation without visible evidence of damage (Chamnongpol et al., 1998; Kovalchuck et al., 2003; Pell et al., 1997; Ranieri et al., 1996; Reiling and Davison, 1995; Zheng et al., 2002). Further to this effect, low-dose ozone has also been implicated in the triggering of systemic acquired resistance responses (Durrant and Dong, 2004; Pell et al., 1997; Rao and Davis, 2001) that convey plant resistance to further pathogen attack. The vast amount of research that has characterized the phytotoxicity of gaseous ozone (as a pollutant) may have inadvertently led to an oversight of the prophylactic use of ozone, in the aqueous form, to address common nursery and greenhouse production issues.

Aqueous ozone has long been used as a water treatment technology in a diverse range of applications, including limited use in the treatment of greenhouse irrigation water (Ehret et al., 2001; Guzel-Seydim et al., 2004; Igura et al., 2004; Rice, 1997; Runia, 1994). A strong oxidation potential $(2.07 \mathrm{eV})$ coupled with a relatively short persistence 
period (seconds to minutes) has made aqueous ozone an ideal microbial and chemical contaminant control agent in many commercial settings (e.g., municipal water treatment, food processing, sewage treatment, postharvest storage). These same properties also lend themselves to applications in greenhouse and nursery environments. Particular interest lies in aqueous ozone's potential as an irrigation water remediation technology and as a means to control pathogens without leaving a chemical residue on the consumer product, a drawback of many current pest control strategies and a growing concern amongst consumers (Miles and Frewer, 2001; Woese et al., 1997).

When introduced into water, the half-life of ozone is variable, but typically it is extremely short because the ozone rapidly reacts with micro-organisms and oxidationprone organic compounds in the water. Ozone that is not consumed through these pathways quickly converts to reactive oxygen-containing free radical species, all having very short (nanosecond) half-lives, and eventually to diatomic oxygen $\left(\mathrm{O}_{2}\right)$. The result of this reversion is the absence of direct chemical residues associated with the treatment. This is not to say that other secondary disinfection byproducts (DBP) are absent, although the general consensus is that the DBPs formed under ozonation are far less problematic than those formed by other common water treatment technologies (e.g., chlorine; Rakness, 2005). The act of creating and dissolving ozone in irrigation water also leads to enhanced dissolved oxygen content. Enhanced oxygenation has been shown to have benefits in terms of improved productivity and pathogen control in greenhouse production (Zheng et al., 2007).

This study presents early steps toward developing a broader understanding of the phytotoxic characteristics of aqueous ozone when applied foliarly. Understanding a crop's tolerance threshold toward aqueous ozone is a key step in developing aqueous ozone applications that will help growers realize greater returns, while meeting the challenges of a changing marketplace and operational environment.

\section{Materials and Methods}

Plant material. Five economically significant woody perennial nursery species [Salix integra 'Hakura Nishiki'; Weigela florida 'Alexandra'; Spiraea japonica 'Goldmound'; Hydrangea paniculata 'Grandiflora'; Physocarpus opulifolius 'Summer Wine'] were selected for the 6-week experiment. The plant material for this study was provided by Canadale Nurseries Limited (St. Thomas, Ontario, Canada; long. $42^{\circ} 47^{\prime} 58^{\prime \prime} \mathrm{N}$, lat. $\left.81^{\circ} 12^{\prime} 52^{\prime \prime} \mathrm{W}\right)$. A detailed description of the plants used in this study and growth media used are described in Cayanan et al. (2008).

The plants were moved from the field into a greenhouse at the University of Guelph (Guelph, Ontario, Canada; long. 43 ${ }^{\circ} 33^{\prime} \mathrm{N}$, lat. $\left.80^{\circ} 15^{\prime} \mathrm{W}\right)$. The move was made in Aug.
2006 and prevented the onset of dormancy and provided more uniform growth conditions. The plants were allowed to acclimate for 5 weeks before beginning the 6-week treatment regime in Oct. 2006. The greenhouse environment control system (Argus Control Systems Ltd., White Rock, British Columbia, Canada) targets were set at $25 / 18^{\circ} \mathrm{C}$ with a 16-h photoperiod supplemented by artificial lighting consisting of 400 and $600-W$ high-pressure sodium and metal halide lights, respectively.

Aqueous ozone preparation and application. Aqueous ozone solutions were prepared at the time of irrigation. Deionized water was fed into a mass transfer loop (Shaw Mixer $^{\mathrm{TM}}$; Purification Research Technologies Incorporated, Guelph, Ontario, Canada) running at a loop pressure of $206.8 \mathrm{kPa}$. The mass transfer loop impinged an ozone gas stream through a venturi injector (Mazzei 584, Bakersfield, CA) on the irrigation water stream. The design of the mass transfer loop was such that the water would undergo the impingement process approximately five times before exiting the loop system. The ozone gas used in the mass transfer loop was generated by passing ambient air through an oxygen concentrator (Workhorse-8 5665; SeQual Technologies Inc., San Diego, CA) that removed the majority of the nitrogen from the air stream, passing the concentrated oxygen $\left(90 \%\right.$ to $\left.95 \% \mathrm{O}_{2}\right)$ through to a corona discharge ozone generator (1500P; Clearwater Tech LLC, San Luis Obispo, CA).

A side stream of the solution containing dissolved ozone was drawn off the mass transfer loop and directed to a dissolved ozone monitor (W1; INUSA Inc., Norwood, MA). The remaining bulk solution was diverted to a bypass until the appropriate dissolved ozone level was achieved, at which time the solution was redirected to the irrigation line supplying the plants at the respective treatment levels. The feed lines (one line for each treatment) were configured in a loop that passed through all the blocks. Branch lines from each of the treatment lines fed overhead emitters at each of the main plots in each block (five branches per treatment line). Each treatment application was maintained for $7.5 \mathrm{~min}$ per treatment, which allowed for an average water delivery of $1 \mathrm{~L} /$ plant.

To minimize the effects of extraneous ozone off-gas (between main plots) during treatment, and to prevent overspray from affecting neighboring plots, an open-topped enclosure was placed around each main plot during treatment. Ambient atmospheric ozone levels were also monitored $(1004 \mathrm{H}$; Dasibi Environmental Corporation, Glendale, CA) and two large carbon filters with a total maximum air handling capacity $48 \mathrm{~m}^{3} / \mathrm{min}$ were placed at random locations throughout the growth area during each daily treatment to prevent gas phase (ozone) cross-contamination among treatments when the high ozone doses were being applied. The system provided sufficient control over extraneous off-gassing such that the ambient ozone levels only periodically and transiently exceeded historic
(1980 to 2006) ambient 1-h maximum ozone levels for the Province of Ontario (3.75 to $6.55 \mathrm{nmol} \cdot \mathrm{L}^{-1}$ ) (Ontario Ministry of the Environment, 2007).

Aqueous ozone determination at canopy height. Practically speaking, it was not feasible to control aqueous ozone levels at each emitter for each treatment level. Ozone levels were set and maintained by drawing off a sample before sending the solution to the distribution system. The length of the distribution system was minimized to reduce the amount of ozone lost during transport to the plants; however, ozone is lost from solution when that solution is atomized or depressurized as is the case at discharge of the emitters. This known loss potential necessitated the measurement of residual ozone at the emitter discharge and at an average canopy height. The canopy height was set to $0.3 \mathrm{~m}$ below the emitter head at a distance of $0.3 \mathrm{~m}$ from the base of the emitter tower. These distances translate into an approximate spray travel distance of $0.47 \mathrm{~m}$ through the air (calculated as one-fourth the circumference of a circle with a radius of $0.3 \mathrm{~m}$ ). Using the gravimetric Indigo colorimetric method (Yates and Stenstrom, 2000), residual ozone concentrations were evaluated in triplicate at each emitter and at each treatment level.

Growth evaluation. On completion of the 6-week treatment period, all plants were destructively sampled. Leaves were excised and passed through a leaf area meter (LI-3100C; LI-COR, Lincoln, NE) and then placed in drying bags along with the woody components of the stem. The combined stem fresh weight was measured (Sartorius LC12000P, Goettingen, Germany) with the average mass of the bag removed. Dry weight was determined by placing the bags in a drying oven at $70{ }^{\circ} \mathrm{C}$ until a constant dry weight was obtained at which point the dry weight was measured. The leaves from a randomly selected plant from each species in each block and each treatment level were separated for leaf damage index determination after which they were also dried to a constant weight. The roots of all the plants were washed by a combination of soaking, agitation, and rinsing in a stainless steel washbasin. The washed roots were placed in paper drying bags and dried to a constant weight. Given the time requirements of the root washing process, the pots were stored in the dark at $4{ }^{\circ} \mathrm{C}$ until they could be processed. In the case of $W$. florida, which flowered during the final $10 \mathrm{~d}$ of the study, the total number of flowers was recorded.

Leaf damage index. Visible leaf damage is a key indicator of plant performance in nursery crops, and the potential for visible injury resulting from aqueous ozone application could have a serious impact on grower and consumer acceptance. To quantify the damage in a more objective fashion, an image analysis protocol was developed to determine the percent damage occurring in a randomly selected subset of the total canopy. Leaves from a randomly selected plant from each species in each treatment were 
positioned on a white, laminated card $(22 \mathrm{~cm}$ $\times 30 \mathrm{~cm})$ coated with a multiuse mild adhesive (Scotch ${ }^{\text {TM }}$ Glue Stick, 3M, St. Paul, $\mathrm{MN}$ ) that allowed the leaves to remain in place during scanning but also allowed for easy removal from the card. The card was labeled with an identification code and placed on a flatbed scanner (A920; DELL, Round Rock, TX). The card was scanned at a resolution of $300 \mathrm{dpi}$ and saved to hard disk as a bitmap image. The images were then preprocessed to remove any image components that were not leaf material (label and scale reference) and to crop the images to a uniform size appropriate for each species [Automator Version 2.0.1 (156); Apple Inc., Cupertino, CA]. Each image was then digitally enhanced to differentiate the damaged and healthy regions (Fig. 1A-B) of the leaves in each image (GIMP 2.4.3 for Mac OS X, GNU Image Manipulation Program, http:// www.gimp.org). The specific image modifications were different for each of the five species examined, because the color of healthy and damaged tissue varied between the species. Threshold, saturation, and hue manipulation allowed for the greatest damage differentiation (Fig. 1C). Common to all the images was the removal of the background color and selection of the damaged and healthy regions by pixel color (varies by species). The removal of the background was accomplished by adding a transparent alpha channel to the image and coloring the dominant background color (white) to that channel, effectively removing the background from the range of analysis colors. After modification of the images (Fig. 1B-C), the damaged regions were easily distinguishable from the healthy regions. The healthy regions were then selected by similar color and isolated from the damaged regions (Fig. 1D). Using the histogram dialogue function, the number of pixels selected as healthy tissue was recorded. Inverting the selection (Fig. 1E) allowed for the total number of pixels associated with damaged tissue to be determined. The leaf damage index (LDI) was calculated by dividing the damaged tissue pixel count by the total leaf area pixel count. The LDI accounts for all damaged tissue, regardless of origin, so the differences evaluated are relative to the control, which was considered to be the baseline.

Leaf gas exchange. Leaf intercellular $\mathrm{CO}_{2}$ concentration, $g_{\mathrm{S}}$, and net $\mathrm{CO}_{2}$ assimilation rate were measured on the last fully expanded leaf at Week 2 and Week 4 of the experiment. Measurements were made using a portable photosynthesis measurement system (LI6400; LI-COR Biosciences, Lincoln, NE).

Flower production. Of the species examined, only $W$. florida reached flowering stage. Flower numbers were tracked and the total

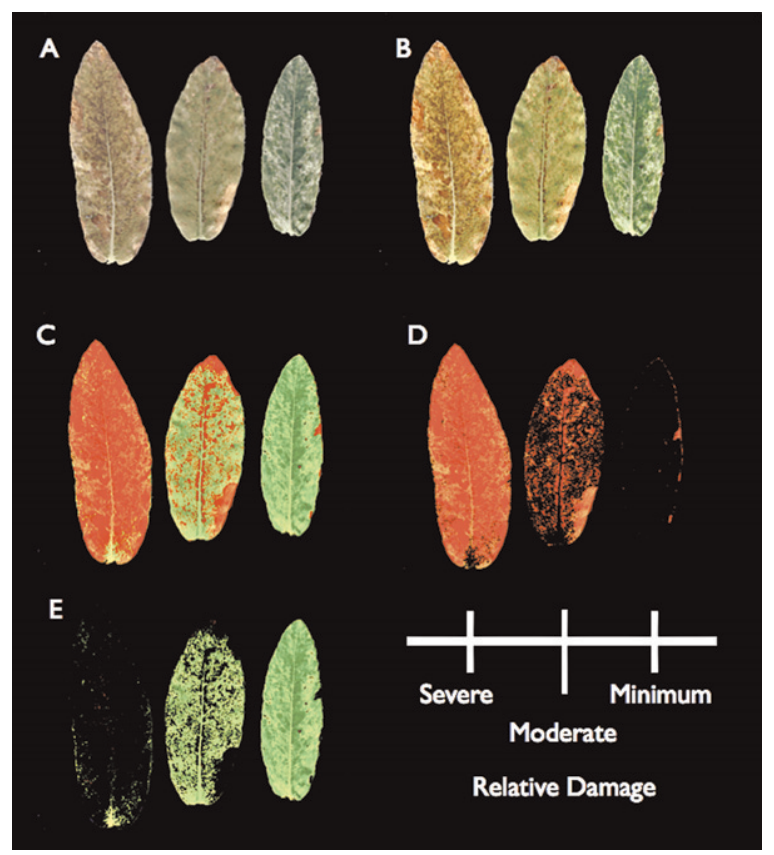

Fig. 1. Representative steps in the image analysis used to quantify leaf injury [leaf damage index (LDI)]. The representative species shown is $S$. integra. The original, unmodified image (A) illustrates the range of injury symptoms. The leaf to the left represents the most severe injury; the middle leaf represents moderate damage; the right side leaf represents minor/no damage. (B) Contrast and brightness enhancements aid in differentiating damaged sections. (C) Hue and saturation levels were optimized to split the damaged and healthy tissue into two narrow color bands that are easily distinguished. (D) Healthy tissue pixels were selected by color using the "select by color" tool in the image manipulation software (GIMP). The selected tissue was then temporarily deleted and the pixel count of the damaged tissue was read. (E) The selection process was reversed with the damaged tissue pixels being removed. This was done to confirm the process and to ensure that the total pixel count was accurate. The images presented are only intended as a sample. The actual analysis was carried out on a much larger scale to ensure that the individual LDI was representative of the entire plant. The black background has been added for publication contrast. (For a color representation, please see online color version.)

number produced per plant was recorded after the 6-week treatment period.

Experimental design and statistical analysis. The experiment was arranged as a randomized complete block design with five blocks containing five treatment levels. Ozone treatment levels were randomly assigned to one of five emitters in each block. Three plants from each species were arranged in a cluster and placed around the emitter.

Statistical analysis was performed using the generalized linear model in SAS 9.13 (SAS, Cary, NC). Treatment means were separated with the least significant difference test if the main treatment effect was significant at $P \leq 0.05$. Leaf damage indices were analyzed through one-way analysis of variance followed by Dunnett's posttest using GraphPad Prism version 5.0a for Mac (GraphPad Software, San Diego, CA).

\section{Results}

Applied ozone dose. Dissolved ozone concentrations at an average plant canopy height $0.3 \mathrm{~m}$ below the emitters were $\approx 30 \%$ that of the concentrations measured at the emitter discharge (Fig. 2). The actual amount of ozone remaining in the solutions after traveling $0.47 \mathrm{~m}$ through the air was 3.54 , 9.42, 17.80, and $29.00 \mu \mathrm{mol} \cdot \mathrm{L}^{-1}$ for the respective nonzero ozone treatments.

Final harvest data. In all five species, the growth patterns and LDI impacts were similar (Fig. 3A-F; Table 1). Salix integra was the most vigorous species in terms of new growth; the results for this species are presented graphically (Fig. 3A-F) and are considered representative of the overall trend for all five species (Table 1). There is a clear damage threshold between 31.2 and 62.5 $\mu \mathrm{mol} \cdot \mathrm{L}^{-1}$; however, the specific threshold value cannot be refined any further given the scope of this study. In the two highest treatments, it was observed that the new growth initiated after the third week of the study showed greatly reduced leaf damage, especially in S. integra.

Leaf gas exchange. The net $\mathrm{CO}_{2}$ assimilation rate (A), intercellular $\mathrm{CO}_{2}$ concentration $\left(\mathrm{c}_{\mathrm{i}}\right)$, and leaf $g_{\mathrm{S}}$ data are presented in Figure 4, Table 2, and Table 3. All four species measured at Week 2 (Fig. 4; Table 2) showed a reduced (or variable) $\mathrm{CO}_{2}$ assimilation rate, intercellular $\mathrm{CO}_{2}$ concentration, and leaf $g_{\mathrm{S}}$ relative to the control. The variation in the response between treatments was not maintained when measured at Week 5 (Fig. 4; Table 3).

Flower production. Overall, there was a minor increase in flower number at the 10.4 $\mu \mathrm{mol} \cdot \mathrm{L}^{-1}$ treatment level and a decrease in the number of flowers produced at 125.0 $\mu \mathrm{mol} \cdot \mathrm{L}^{-1}$ in $W$. florida, the only plant that flowered during this study (Fig. 5).

\section{Discussion}

Our results indicate that there is a reasonably defined aqueous ozone phytotoxic 


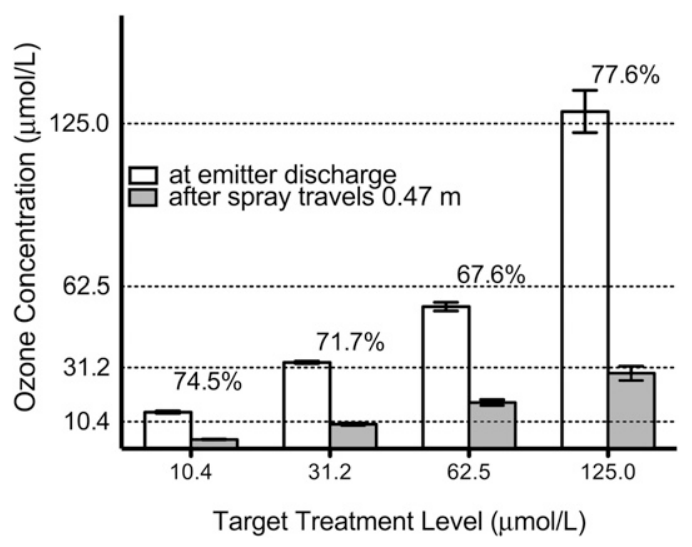

Fig. 2. Ozone loss from solution as a result of spraying. The value (percent) above each group is the calculated percent ozone loss from solution after the solution is discharged from the emitter and travels an average distance of $0.47 \mathrm{~m}$ through the air. Error bars are \pm sE based on 30 measurements.

A
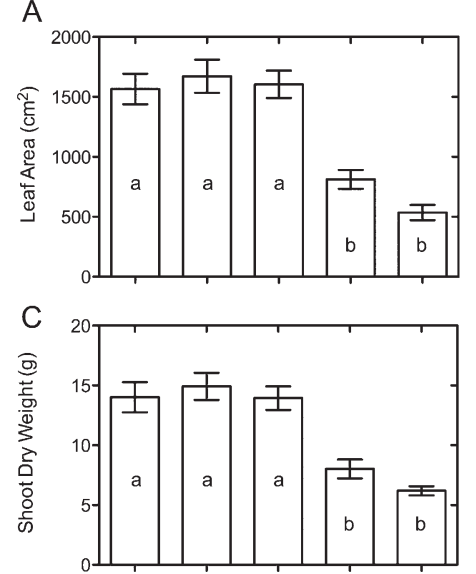

E

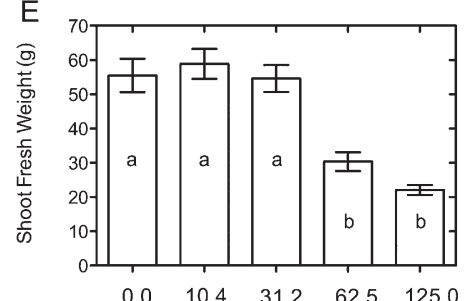

$\begin{array}{llll}10.4 & 31.2 & 62.5 & 125.0\end{array}$
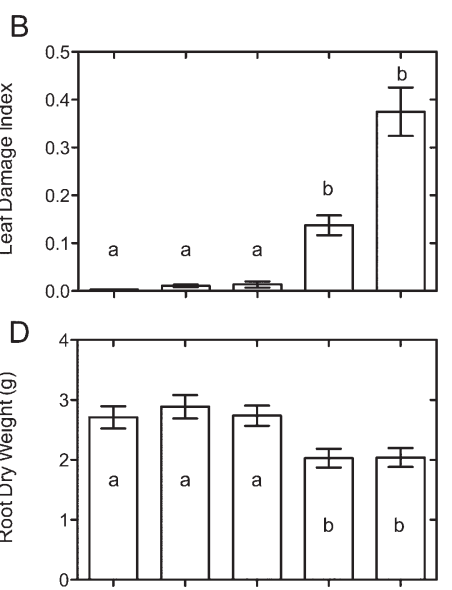

$\mathrm{F}$

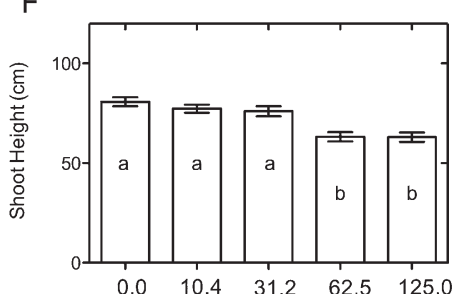

Target Aqueous Ozone Concentration at Discharge (umol/L)

Fig. 3. Response of $S$. integra to overhead irrigation with different aqueous ozone solutions. Bars represent the average for each parameter $\pm \mathrm{SE}$ at each dose level measured during the destructive sampling of the plants after 6 weeks of daily treatments. Treatment means with the same letter are not different at $P \leq$ 0.05 .

threshold under the exposure conditions used for the five species examined. Given the data and taking into account experimental limitations, it can be stated that this threshold lies between 31.2 and $62.5 \mu \mathrm{mol} \cdot \mathrm{L}^{-1}$ (at emitter discharge) over a 7.5-min application period. Below $31.2 \mu \mathrm{mol} \cdot \mathrm{L}^{-1}$, there were no negative effects of the ozone application relative to the control. Slight (although not significant at $P \leq 0.05)$ improvements in performance (Fig. 3) were suggested under low-dose $\left(10.4 \mu \mathrm{mol} \cdot \mathrm{L}^{-1}\right)$ aqueous ozone application. Furthermore, the gas exchange data (Fig. 4; Tables 2 and 3) suggest that there was an adaptation to the oxidative environment imposed. This trend was supported by visual inspection of foliage ( $S$. integra) produced during the treatment period. The in-treatment foliage showed reduced incidence of damage compared with foliage present before the treatments started. This reduced damage is seen in the leaf image analysis data (Fig. 3; Table 1) in which, even at the highest treatment levels, the percent damage is still below $50 \%$. Leaves present before the treatments $\left(62.5,125.0 \mu \mathrm{mol} \cdot \mathrm{L}^{-1}\right)$ started were severely damaged (see Fig. 1, severe damage example) with an estimated damage index of 0.9 , whereas foliage produced after treatments started had moderate to minor damage. The aggregate leaf damage served to reduce the overall LDI for the highest treatments, although significant damage was still realized overall at these treatment levels.

Ozone (aqueous) loss as a result of spraying proved to be substantial (Fig. 2). This loss confounds the conclusions to some degree, because the concentration realized at the leaf surface is considerably lower than the concentration present in the distribution system and at the emitter discharge. Given this loss, the threshold, as measured at the average canopy height, can be estimated as $30 \%$ of the measured threshold in the distribution system. When developing protocols for irrigation system maintenance using aqueous ozone, this loss along with the corresponding increase in gas phase ozone must be a design consideration.

In this study, ozone off-gas was contained to a greater degree than it would be in an open-air nursery situation or during summer greenhouse production when vents would be fully opened. Even with the greater degree of closure, atmospheric dilution and the short half-life of ozone resulted in only minor gas phase ozone increases (at subsymptomatic treatment levels) as compared with a normal summer day in eastern North America (Ontario Ministry of the Environment, 2007). Although ozone gas levels did rise in the greenhouse, the spikes were transient, resulting in only minor periodic exposures (compared with typical smog events) well below the levels that are associated with long-term production influences (Langebartels et al., 1998). These transient spikes may be a concern from a worker safety point of view and must be considered in any future system development.

The factors affecting plant response to ozone are numerous and diverse. Previous exposure (adaptation), water status, stomatal functioning, genetics, duration and severity of the exposure, cuticular composition, environmental conditions (wind speed, humidity, temperature), and plant developmental stage are just a few of the parameters governing the mass transfer of ozone into a plant and the physiological responses occurring thereafter (Heagle, 1989; Kerstiens and Lendzian, 1989; Lyons and Barnes, 1998; Pasqualini et al., 2002; Sandermann, 1996). For these reasons, a simple, universal toxicity threshold cannot be determined, yet the evidence presented clearly indicates that the crop species examined can tolerate aqueous ozone concentrations that are useful in terms of pathogen and chemical contaminant control in nursery and greenhouse irrigation systems.

The phytotoxic effects of gaseous ozone (at pollutant levels) are reasonably well understood, although many questions still remain regarding stomatally controlled mass transfer, internal distribution of ozone, direct versus indirect effects, and physiological systems affected within the leaf and plant proper (Altimir et al., 2008; Fuhrer and Booker, 2003; Langebartels et al., 2002; Pell et al., 1997; Sandermann, 1996). Application of ozone in the aqueous state further complicates the situation by influencing mass transfer dynamics, thermodynamic conditions, 


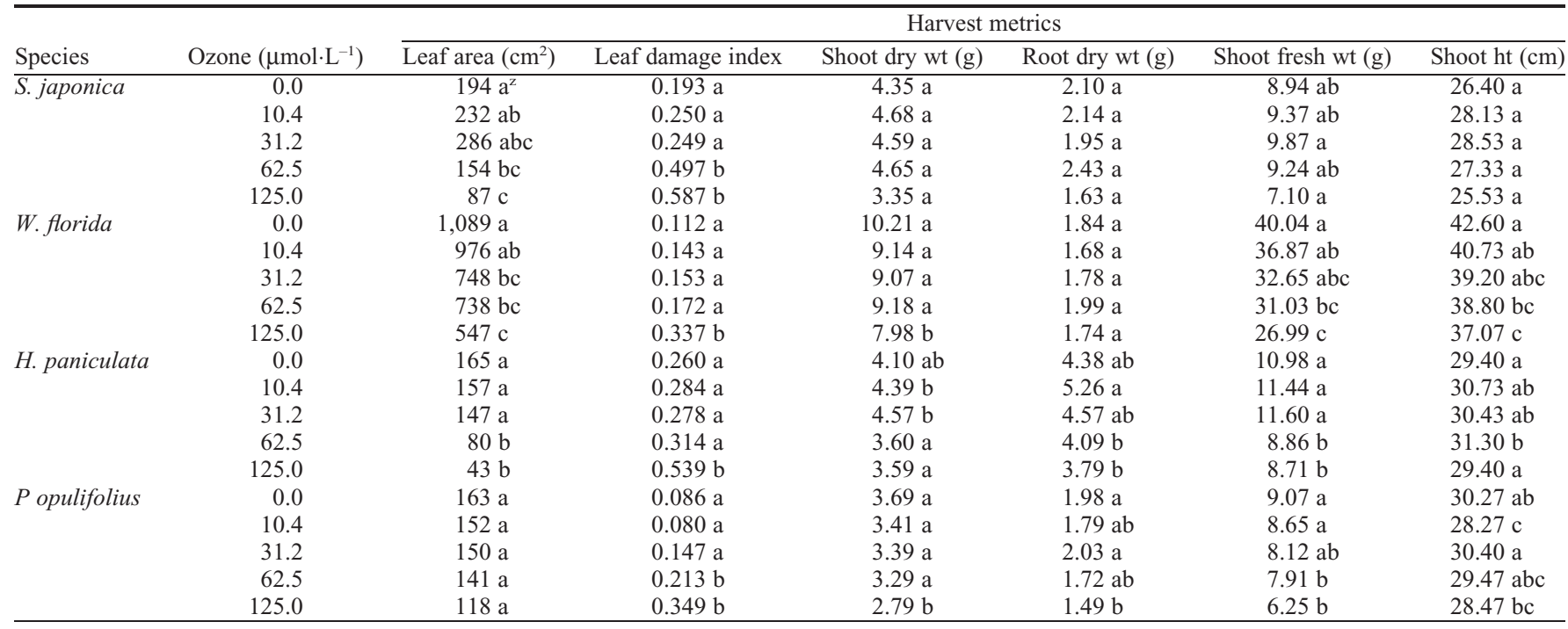

${ }^{\mathrm{z}}$ Treatment means (within columns and species) with the same letter are not different at $P \leq 0.05$.
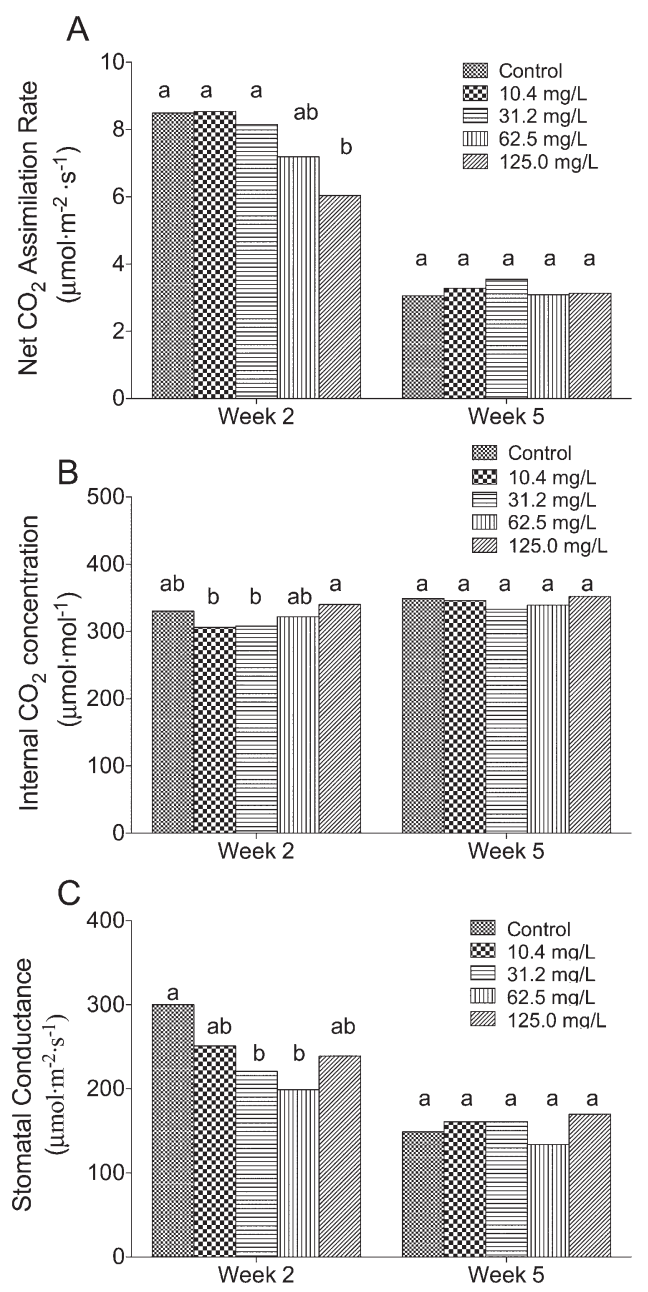

Fig. 4. Leaf net $\mathrm{CO}_{2}$ assimilation rate $(\mathbf{A})$, intercellular $\mathrm{CO}_{2}$ concentration $(\mathbf{B})$, and $g_{\mathrm{S}}(\mathbf{C})$ for $S$. integra at five different aqueous ozone treatment levels measured at Week 2 and Week 5. Columns within each group with the same letter are not significantly different at $P \leq 0.05$.

reaction pathways, and boundary layer conditions. In addition, the method of application will also play a significant role in determining the phytotoxic threshold, because this will influence ozone mass transfer from the irrigation solution to the canopy atmosphere (Fujiwara and Fujii, 2004). The results obtained under the presented experi- mental conditions support the work of others (Fujiwara and Fujii, 2002) that suggests ozone applied in aqueous solution does not interact with plants in the same fashion as gas phase ozone. The mechanisms of this difference remain to be determined and will no doubt hold strict license on the design and application of aqueous ozone systems in a nursery setting.

The aqueous ozone phytotoxic threshold established under the presented experimental conditions was sufficiently high to accommodate the practical application of aqueous ozone in irrigation distribution systems. The application of ozone at these levels should allow for the control algae and biofilm development and has potential to lower pathogen loads, a particularly important consideration when recirculating irrigation systems are used. In the absence of any direct plant productivity benefits, aqueous ozone could still improve profit margins by reducing irrigation system maintenance and reducing the pathogen load associated with untreated and recycled irrigation water.

Given that ozone exposure, as a component of photochemical smog, is a significant plant production issue in many key North American and European nursery production areas (Heagle, 1989), it is intriguing to conceptualize ozone "immunization" protocols that enhance natural tolerance to the oxidant. Methods of artificially inducing ozone resistance exist (Heagle, 1989; Heath, 1996; Lenhardt, 1993); however, it may be that the best option for stimulating tolerance development is through the application of ozone itself. Given the tight control that modern systems offer for the delivery and dose of aqueous ozone (relative to pollution events), and the adaptation to ozone that has been demonstrated by others (Kovalchuck et al., 2003; Lyons and Barnes, 1998), it stands to reason that it would be possible to slowly acclimate seedlings and young nursery stock to ozone stress by applying it early in the growth season when pollution events 
Table 2. Leaf net $\mathrm{CO}_{2}$ assimilation rate (A), intercellular $\mathrm{CO}_{2}$ concentration $\left(\mathrm{c}_{\mathrm{i}}\right)$, and stomatal conductance $\left(g_{\mathrm{S}}\right)$ for $W$. florida, H. paniculata, and P. opulifolius at five different treatment levels (Week 2).

\begin{tabular}{lcccc}
\hline Species $^{\mathrm{y}}$ & {$\left[\mathrm{O}_{3}\right]_{\mathrm{aq}}\left(\mu \mathrm{mol} \cdot \mathrm{L}^{-1}\right)$} & $\mathrm{A}\left(\mu \mathrm{mol} \cdot \mathrm{m}^{-2} \cdot \mathrm{s}^{-1}\right)$ & $\mathrm{c}_{\mathrm{i}}\left(\mu \mathrm{mol} \cdot \mathrm{mol}^{-1}\right)$ & $\mathrm{g}_{\mathrm{s}}\left(\mu \mathrm{mol} \cdot \mathrm{m}^{-2} \cdot \mathrm{s}^{-1}\right)$ \\
\hline W. florida & 0.0 & $8.71 \mathrm{a}^{\mathrm{z}}$ & $334 \mathrm{a}$ & $304 \mathrm{ab}$ \\
& 10.4 & $8.61 \mathrm{a}$ & $334 \mathrm{a}$ & $28.3 \mathrm{~b}$ \\
& 31.2 & $7.17 \mathrm{~b}$ & $348 \mathrm{~b}$ & $339 \mathrm{ab}$ \\
H. paniculata & 62.5 & $8.12 \mathrm{ab}$ & $346 \mathrm{~b}$ & $362 \mathrm{a}$ \\
& 125.0 & $7.45 \mathrm{ab}$ & $344 \mathrm{ab}$ & $314 \mathrm{ab}$ \\
& 0.0 & $16.65 \mathrm{a}$ & $182 \mathrm{a}$ & $173 \mathrm{a}$ \\
& 10.4 & $16.14 \mathrm{ab}$ & $119 \mathrm{a}$ & $123 \mathrm{~b}$ \\
P. opulifolius & 31.2 & $15.54 \mathrm{bc}$ & $117 \mathrm{a}$ & $113 \mathrm{~b}$ \\
& 62.5 & $15.04 \mathrm{c}$ & $133 \mathrm{a}$ & $102 \mathrm{~b}$ \\
& 125.0 & $14.77 \mathrm{c}$ & $112 \mathrm{a}$ & $95 \mathrm{~b}$ \\
& 0.0 & $11.61 \mathrm{a}$ & $342 \mathrm{a}$ & $480 \mathrm{a}$ \\
& 10.4 & $11.08 \mathrm{ab}$ & $345 \mathrm{a}$ & $495 \mathrm{a}$ \\
& 31.2 & $11.27 \mathrm{a}$ & $345 \mathrm{a}$ & $514 \mathrm{a}$ \\
& 62.5 & $9.72 \mathrm{~b}$ & $353 \mathrm{~b}$ & $514 \mathrm{a}$ \\
\hline
\end{tabular}

${ }^{z}$ Treatment means (within column) with the same letter do not differ significantly at $P \leq 0.05$.

${ }^{y} S$. japonica is excluded as its leaves were too small for the measurement chamber; $S$. integra is presented in Figure 4.

Table 3. Leaf net $\mathrm{CO}_{2}$ assimilation rate (A), intercellular $\mathrm{CO}_{2}$ concentration $\left(\mathrm{c}_{\mathrm{i}}\right)$, and stomatal conductance $\left(g_{\mathrm{S}}\right)$ for $W$. florida, H. paniculata, and P. opulifolius at five different treatment levels (Week 5).

\begin{tabular}{lcccc}
\hline Species $^{\mathrm{y}}$ & {$\left[\mathrm{O}_{3}\right]_{\mathrm{aq}}\left(\mu \mathrm{mol} \cdot \mathrm{L}^{-1}\right)$} & $\mathrm{A}\left(\mu \mathrm{mol} \cdot \mathrm{m}^{-2} \cdot \mathrm{s}^{-1}\right)$ & $\mathrm{c}_{\mathrm{i}}\left(\mu \mathrm{mol} \cdot \mathrm{mol}^{-1}\right)$ & $\mathrm{g}_{\mathrm{s}}\left(\mu \mathrm{mol} \cdot \mathrm{m}^{-2} \cdot \mathrm{s}^{-1}\right)$ \\
\hline W. florida & 0.0 & $6.40 \mathrm{a}^{\mathrm{z}}$ & $329 \mathrm{a}$ & $206 \mathrm{a}$ \\
& 10.4 & $6.68 \mathrm{a}$ & $336 \mathrm{a}$ & $235 \mathrm{a}$ \\
& 31.2 & $5.93 \mathrm{a}$ & $332 \mathrm{a}$ & $211 \mathrm{a}$ \\
H. paniculata & 62.5 & $6.28 \mathrm{a}$ & $327 \mathrm{a}$ & $214 \mathrm{a}$ \\
& 125.0 & $5.72 \mathrm{a}$ & $335 \mathrm{a}$ & $188 \mathrm{a}$ \\
& 0.0 & $5.89 \mathrm{a}$ & $328 \mathrm{a}$ & $184 \mathrm{a}$ \\
& 10.4 & $5.66 \mathrm{a}$ & $317 \mathrm{ab}$ & $143 \mathrm{~b}$ \\
P. opulifolius & 31.2 & $4.54 \mathrm{a}$ & $286 \mathrm{~b}$ & $99 \mathrm{c}$ \\
& 62.5 & $4.68 \mathrm{a}$ & $295 \mathrm{ab}$ & $89 \mathrm{c}$ \\
& 125.0 & $4.30 \mathrm{a}$ & $301 \mathrm{ab}$ & $90 \mathrm{c}$ \\
& 0.0 & $9.92 \mathrm{a}$ & $341 \mathrm{a}$ & $397 \mathrm{a}$ \\
& 10.4 & $9.65 \mathrm{a}$ & $340 \mathrm{a}$ & $383 \mathrm{a}$ \\
& 31.2 & $9.62 \mathrm{a}$ & $341 \mathrm{a}$ & $392 \mathrm{a}$ \\
& 62.5 & $8.93 \mathrm{a}$ & $348 \mathrm{a}$ & $435 \mathrm{a}$ \\
\hline
\end{tabular}

${ }^{z}$ Treatment means (within column) with the same letter do not differ significantly at $P \leq 0.05$.

${ }^{\mathrm{y}} S$. japonica is excluded as its leaves were too small for the measurement chamber; $S$. integra is presented in Figure 4.

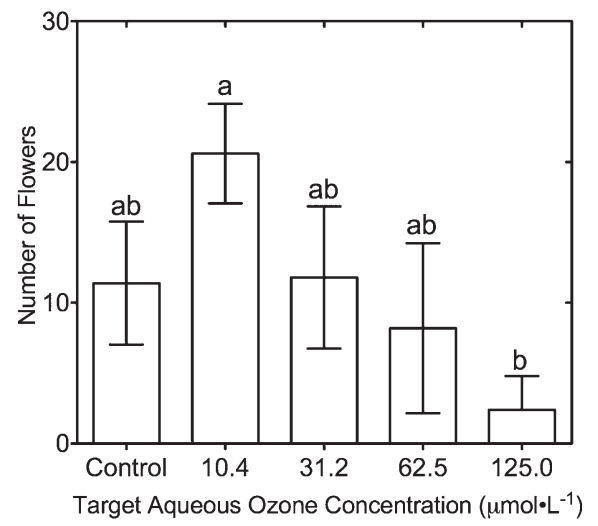

Fig. 5. Average flower production for $W$. florida after 6 weeks of irrigation with aqueous ozone solutions (1 L/plant per day). Columns with the same letter do not differ at $P \leq 0.05$. Data are mean $\pm \mathrm{SE}$.

are rare. Early adaptation may help mitigate the visible damage that can result after a substantial smog event, damage that can dramatically reduce the value of the nursery product.

Ozone gas, above critical thresholds, is a known phytotoxic compound and great care
Durrant, W.E. and X. Dong. 2004. Systemic acquired resistance. Annu. Rev. Phytopathol. 42:185-209.

Ehret, D.L., B. Alsanius, W. Wohanka, J.G. Menzies, and R. Utkhede. 2001. Disinfestation of recirculating nutrient solutions in greenhouse horticulture. Agronomie 21:323-339.

Fiscus, E., F. Booker, and K. Burkey. 2005. Crop responses to ozone: Uptake, modes of action, carbon assimilation and partitioning. Plant Cell Environ. 28:997-1011.

Fuhrer, J. and F. Booker. 2003. Ecological issues related to ozone: Agricultural issues. Environ. Int. 29:997-1011.

Fujiwara, K. and T. Fujii. 2002. Effects of spraying ozonated water on the severity of powdery mildew infection on cucumber leaves. Ozone Sci. Eng. 24:463-469.

Fujiwara, K. and T. Fujii. 2004. Research note: Effects of ozonated water spray droplet size and distance on the dissolved ozone concentration at the spray target. Ozone Sci. Eng. 26:511-516.

Guzel-Seydim, Z.B., A.K. Greene, and A.C. Seydim. 2004. Use of ozone in the food industry. LWT-Food Sci. Technol. 37:453-460.

Heagle, A. 1989. Ozone and crop yield. Annu. Rev. Phytopathol. 27:397-423.

Heath, R.L. 1996. The modification of photosynthetic capacity induced by ozone exposure, $\mathrm{p}$. 409-433. In: Baker, N.R. (ed.). Photosynthesis and the environment. Kluwer Academic Publishers, Dordrecht, The Netherlands.

Hong, C.X. and G.W. Moorman. 2005. Plant pathogens in irrigation water: Challenges and opportunities. Crit. Rev. Plant Sci. 24:189-208.

Igura, N., M. Fujii, M. Shimoda, and I. Hayakawa 2004. Research note: Inactivation efficiency of ozonated water for Fusarium oxysporum conidia under hydroponic greenhouse conditions. Ozone Sci. Eng. 26:517-521.

Johansson, R.C., Y. Tsur, T. Roe, R. Doukkali, and A. Dinar. 2002. Pricing irrigation water: A review of theory and practice. Water Policy 4:173-199.

Kerstiens, G. and K.J. Lendzian. 1989. Interactions between ozone and plant cuticles. I. Ozone deposition and permeability. New Phytol. 12:13-19.

Kovalchuck, I., J. Filkowski, K. Smith, and O. Kovalchuck. 2003. Reactive oxygen species stimulate homologous recombination in plants. Plant Cell Environ. 26:1531-1539.

Langebartels, C., W. Heller, D. Ernst, G. Füher, M. Lippert, S. Simons, and H. Sandermann, Jr. 1998. Memory effects in the action of ozone on conifers. Ecotoxicol. Environ. Saf. 41:62-72.

Langebartels, C., H. Wohlgemuth, and S. Kschieschan. 2002. Oxidative burst and cell death in ozone-exposed plants. Plant Physiol. Biochem. 40:567-575.

Lenhardt, P.J. 1993. The effect of ethylenediurea on tomato (Lycopersicon esculentum Mill. cv. New Yorker). Univ. of Guelph, Guelph, Ontario, Canada, $\mathrm{PhD}$ Thesis. p. 173.

Lyons, T.M. and J.D. Barnes. 1998. Influence of plant age on ozone resistance in Plantago major. New Phytol. 138:83-89.

Miles, S. and L.J. Frewer. 2001. Investigating specific concerns about different food hazards. Food Qual. Prefer. 12:47-61.

Ontario Ministry of the Environment. 2007. Air quality in Ontario: 2006 report. Queen's Printer for Ontario. PIBS 6552e.

Pasqualini, S., M. Antonielli, L. Ederli, and C. Piccioni. 2002. Ozone uptake and its effect on photosynthetic parameters of two tobacco 
cultivars with contrasting ozone sensitivity. Plant Physiol. Biochem. 40:599-603.

Pell, E., C. Schlagnhaufer, and R. Arteca. 1997. Ozone-induced oxidative stress: Mechanisms of action and reaction. Physiol. Plant. 100:264 273.

Province of Ontario Parliament, House of Commons. Ontario Water Resources Act, R.S.O. 1990, c. O.40. 25 Nov. 2008. <http://www.canlii. org/on/laws/sta/o-40/20070516/whole.html>.

Rakness, K.L. 2005. Ozone in drinking water treatment: Process design, operation and optimization. 1st Ed. American Water Works Association, Denver, CO.

Ranieri, A., G. D’Urso, C. Nali, G. Lorenzini, and G.F. Soldatini. 1996. Ozone stimulates apoplastic antioxidant systems in pumpkin leaves. Physiol. Plant. 97:381-387.

Rao, M. and K. Davis. 2001. The physiology of ozone induced cell death. Planta 213:682-690.
Reiling, K. and A.W. Davison. 1995. Effects of ozone on stomatal conductance and photosynthesis in populations of Plantago major L. New Phytol. 129:587-594.

Rice, R.G. 1997. Applications of ozone for industrial wastewater treatment-A review. Ozone Sci. Eng. 18:477-515.

Runia, W.T. 1994. Disinfection of recirculation water from closed cultivation systems with ozone. Acta Hort. 361:388-396.

Sandermann H., Jr. 1996. Ozone and plant health. Annu. Rev. Phytopathol. 34:347-366.

Sloan, J.J. and M.C. Engelke. 2005. Effect of ozonated water on creeping bentgrass growth in a sand medium. HortTechnology 15:148-152.

Uri, N.D. 1998. Government policy and the development and use of biopesticides. Futures 30:409-423.

Woese, K., D. Lange, C. Boess, and K.W. Bögl. 1997. A comparison of organically and con- ventionally grown foods-Results of a review of the relevant literature. J. Sci. Food Agr. 74:281-293.

Yates, R.S. and M.L. Stenstrom. 2000. Gravimetric sampling procedure for aqueous ozone concentrations. Water Res. 34:1413-1416.

Yiridoe, E.K., B.A. Samuel, and M.C. Ralph. 2005. Comparison of consumer perceptions and preference toward organic versus conventionally produced foods: A review and update of the literature. Renewable Agr. Food Syst. 20:193205.

Zheng, Y., H. Shimizu, and J.D. Barnes. 2002. Limitations to $\mathrm{CO}_{2}$ assimilation in ozoneexposed leaves of Plantago major. New Phytol. 155:67-78.

Zheng, Y., L. Wang, and M. Dixon. 2007. An upper limit for elevated root zone dissolved oxygen concentration for tomato. Sci. Hort. 113:162165 . 